\title{
"I want to go again and again": Spiritual Emotions And Self-Improvement Through Pilgrimage
}

\author{
Claudia Seise \\ International Islamic University Malaysia \\ Corresponding Author: claudiaseise@iium.edu.my; claudia@seise.de
}

\begin{abstract}
ARTICLE INFO
Publication Info:

Research in Progress Article

How to cite:

Seise, C. (2019). "I want to go again and again": Spiritual

Emotions And Self-Improvement

Through Pilgrimage. Society, 7(1), 1-10.

DOI : 10.33019/society.v7i1.75

Copyright $\odot$ 2019. Owned by Author(s), published by Society

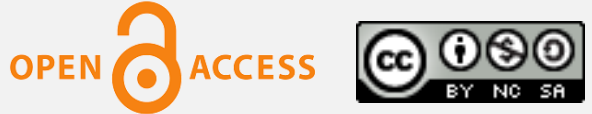

ABSTRACT

This article aims to understand what it is that has made and still makes millions of Muslims taking great physical and financial hardship to go on the Muslim pilgrimage. It seems that the reason why Muslims yearn to visit Mecca has to be understood by looking at what emotions, and especially spiritual emotions, are triggered through this visit or even through the imagination of visiting the holy land. This yearning cannot just be understood based on wanting to fulfill one of the five pillars of Islam. Religious or spiritual travel like the journey to the holy land of Islam needs to be understood within the context of an individual's emotional landscape, spiritual development and urge for spiritual self-improvement to become a better person and Muslim. This article used qualitative method, particularly semi-structured interviews with the informants. The results showed that pilgrimage to the Muslim holy land in Mecca can be a changing experience for the pilgrim undertaking the journey.
\end{abstract}

This is an open access article.

License: Attribution-

NonCommercial-ShareAlike (CC BY-NC-SA)
Keywords: Hajj; Islam; Muslim Women; Pilgrimage; Spiritual Emotions; Umrah;

\section{Introduction}

Visiting the Muslim holy land, the house of God and the mosque of the Holy Prophet Muhammad has been the destination and dream of millions of Muslims from all around the world. In Islam, it is obligatory upon every Muslim who has the financial means to go on the Muslim pilgrimage, hajj, once in his lifetime. However, it is not only about the obligation to fulfill God's command that is behind this enormous movement of people but the deep emotional connection to a place that is viewed to be the center of the Muslim world 
and the center of a person's worship. It is towards Mecca where Muslims turn in their five daily obligatory ritual prayers. Pilgrims peregrinate toward what they perceive as their sociocultural center (Cohen 1992). That is also true for the pilgrimage to Mecca in present-day Saudi Arabia. Muslims have gone through arduous journeys to reach the place of their spiritual dreams; crossed desserts and oceans, war-torn lands and arbitrarily fixed national boundaries (Tagliacozzo 2013). They have saved up the money for ten, twenty, thirty years, every day a little amount to come closer to their lifetime dream. For many, it is a journey they intend to do only once in their lives. A journey, they do not know whether they will ever return from. Many Muslims reported carrying the wish in their hearts to die in the holy land. In their journey to the holy Kaaba, they follow the established way passed down by the Prophet Muhammad. $\mathrm{He}$, in turn, followed what has been revealed to him about the pilgrimage of the father of Islam, Christianity and Judaism, the Prophet Abraham, called Ibrahim in the Islamic tradition.

Since Islam reached the Indonesian archipelago from the $8^{\text {th }}$ century onward, Indonesian Muslims, like their brothers and sisters elsewhere, have also strived to reach the holy land and ritual center of Islam. Indonesia is the most populous Islamic country in the world. Around 200 Million people who identify themselves as Muslims live in this biggest Southeast Asian country and the world's largest archipelago. However, their geographical location, which is often understood to be in the periphery of the Muslim world, and the distance from the so-called Muslim heartland used to make their journey, at least in the past, an even greater challenge compared to Muslims from other parts of the world.

Following, this article gives a short introduction to pilgrimages and especially the Muslim pilgrimage. I will focus on spiritual emotions and especially the emotion of khushu (commonly referred to as focus of mind and heart during prayer). I will show that learning how to feel spiritual emotions is desirable both in terms of knowledge acquisition as well as for the collection of divine reward. Furthermore, to learn spiritual emotions also impacts on a person's worldly life. The second part of this article will turn to spiritual selfimprovement with a concrete example from Leila's narrative, a Muslim woman. Her narrative illustrates how the urge to improve a person's spirituality through pilgrimage leads to changes in her life both in terms of spiritual and more worldly elements. This quest for piety (Nolan \& Nolan 1989), I argue, is also partly calculative in nature. Calculative reason applied by the pilgrims to gain divine reward and to improve their worldly lives cannot be overlooked. They form an essential intention and a driving force to undertake the Muslim pilgrimage.

This study used qualitative research methods, particularly semi-structured interviews with Indonesian Muslim women living in Germany. My informants, Leila and Maryam, have told me extensively about their experiences and spiritual emotions during their hajj and umrah ${ }^{1}$. This article focuses on Indonesian women because, coming from a Southeast Asian studies background, my primary research focus is Islam in Indonesia ${ }^{2}$. This article is

1 Besides the accounts of Leila and Maryam
presented here, my findings and discussion in this
article are also influenced by personal talks with
Muslim friends who returned from hajj or umrah.
Since my conversion to Islam in 2010, I have been
listening to dozens of Muslim friends who related
their experiences and feelings during hajj or umrah.
2 I chose to focus on Indonesian women because I
feel it easy to talk to them about this topic and
especially their emotions. I have been doing research
in Indonesia for a total of almost two years and have
lived in Indonesia for a total of around four years. I 
discussing research in progress. By publishing this article at a rather early stage, I aim to generate feedback on the concepts and approaches introduced here.

\section{Findings and Discussion}

\section{Pilgrimages}

More and more people from different religions go on different kinds of pilgrimages. Pilgrimage is experiencing resurgence around the world (Digance 2003, 2006). The Muslim pilgrimage, hajj, or the small Muslim pilgrimage, umrah, to Mecca, is no exception. Pilgrimages have powerful political, economical, social, and cultural implications, and can even affect global trade and health (Collins-Kreiner 2018). For some countries and cities, it has been a primary economic activity (Barber 1993; Vukonic 1996, 2002), including the Muslim pilgrimage to Mecca in Saudi Arabia. However, as I will show in this article, pilgrimages, and in my case the Muslim pilgrimage to Mecca, also has an immense emotional implication. Emotions experienced during pilgrimage can trigger spiritual transformations in the pilgrims. And these, in turn, can affect the surroundings and society of the individual experiencing these emotions.

Muslim doctrine enjoins and encourages certain forms of travel like the hajj, hijra (leaving a place where the practice of Islam is restricted for a place where no such restrictions exist), ziarah (visiting graves of Muslim saints or scholars), or rihla

speak fluently Indonesian and have come to know the people, their way of thinking and how to best approach an interview. Interviews for this article were conducted in Indonesian. Furthermore, I decided to focus on women because after doing research with mainly male informants for my Ph.D. which came with several challenges, I think that as a female Muslim researcher, talking about spiritual emotions would not be quite as easy with male informants as it would be with female informants. (traveling for educational purposes) (Eickelman \& Piscatori 1990; Tagliacozzo 2013). However, I argue, that religious or spiritual travel like the journey to the holy land of Islam needs to be understood within the context of an individual's emotional landscape, spiritual development and urge for spiritual self-improvement to become a better person and Muslim. It seems that individual's spiritual emotions, triggered through personal experiences while in the holy land, move a person to improve her relationship with the divine as well as her interpersonal relationships. These improvements can eventually make her a more active and productive member of society due to her heightened spiritual awareness and commitment. The knowledge gained through direct spiritual experiences can lead to improving a person's religious practices, deeds and actions. It seems that this kind of knowledge is obtained easier while on hajj or umrah compared to the theoretical knowledge gained by reading books or attending religious lectures.

Collins-Kreiner (2018) argues that pilgrimage must be defined holistically, encompassing both traditional religious pilgrimage and modern secular journeys ${ }^{3}$. However, this article focuses on a traditional religious pilgrimage and the emotions that are inherent in it. Because, while I agree with Collins-Kreiner that traditional religious pilgrimages are becoming more and more entwined with modern secular journeys, I also observed that the urge for traditional religious pilgrimage only is also present. Among Muslims, there exists an urge to focus on the religious aspects only. However, the features of modern secular journeys such as buying gifts and the like, are present as well.

3 Here secular journeys refer to journeys that are not undertaken for a specific religious or spiritual purpose. 
By focusing on the individual's spiritual emotions and development experienced during pilgrimage, I aim to speak to the study of pilgrimage tourism that has focused more attention on individuals and his or her personal experience since the 1990s (Smith 1989, 1992; Cohen 1992; Collins-Kreiner \& Gatrell 2006; Poria, Butler \& Airey 2003, 2004). Furthermore, current research on pilgrimage emphasizes the aspect of subjectivity (Collins-Kreiner 2018).

\section{Talking About Spiritual Emotions}

Spiritual emotions, experiences, and spiritual growth are mostly discussed in research about Christianity and especially Pentecostalism (e.g. Gallagher \& Newton 2009) and the veneration and experience of the so-called holy spirit. Emotions connected to Sufi rituals are also discussed in contemporary literature (e.g. Parveen 2014; Wolf 2000; Powers 2004; Malamud 1996). In addition, spirituality is also discussed when it comes to relating religion, religious practices, belief or spirituality to health or psychological well-being (e.g. Sharp 2010; Fredrickson 2002; Greenfield et. al. 2009; Ahmad et. al. 2011). However, the way I would like to talk about spiritual emotions takes a different approach. I propose to distinguish between religious emotions (Riis \& Woodhead 2010) that are usually expected of a practitioner of religion by the respective religious doctrine, and spiritual emotions that are individually felt and experienced by a person through devotional practice, spiritual experiences or religious travel and pilgrimage.

In their book The Sociology of Religious Emotion (2010), Riis and Woodhead argue that scriptural and theological traditions include religious emotions among their central objectives of religious life. This means that to feel religious or spiritual emotions belongs to a believers religious reality. And "neither the Bible nor the Qur'an - nor the Hebrew scriptures - draws the typically modern contrast between reason and emotion, or subordinates the latter to the former" (Riis \& Woodhead 2010: 3). Concerning Islam, they speak of the Qur'an as an "emotionally self-aware and self-reflective source (that) repeatedly insists on the importance of feeling, and contains intra-textual prompts on the emotions that it is intended to inspire" (ibid: 2). 'Believers', it says, 'are those who, when God is mentioned, feel a tremor in their hearts, and when they hear His signs rehearsed, find their faith strengthened, and put (all) their trust in their Lord' (see Qur'an 8: 2) (ibid).

However, I prefer to speak of spiritual emotions. I take my use of 'spiritual' from the emic perspective ${ }^{4}$ in Islamic teachings about the human spirit or soul called ruh in Arabic. In the Islamic science of tasawwuf, which is usually dubbed Islamic spirituality, it is taught that it is the ruh and especially its spiritual heart, the qalb, that is the seat of a person's emotions. Because ruh, spirit, refers to the inside of a person's being, it is more adequate to speak of spiritual emotions instead of religious emotions. Religious emotions, on the other hand, refer to outside emotions. Because, again taking the emic perspective into account, religion, here Islam, refers to the outside manifestations of a person's worship that can be observed by other people. This is based on the division of Islam in Islam, which is the outside manifestation of worship, Iman, which is usually referred to as belief, and Ihsan, which is the inner, emotional manifestation of worship and a person's relationship with the divine. It is in the third category, Ihsan, where a person's spiritual development, spiritual emotions, spiritual selfimprovement, good behavior and relationship with the divine are located, trained, developed and preserved. It is this

\footnotetext{
4 I was trained in area studies. Taking a view from the inside, emic concepts are an important part of area studies' findings.
} 
inner reform that happens in a person's ruh that can cause a person to become spiritually balanced, which again reflects on her role as an active and productive member of society. That is why, a journey like the hajj or umrah, which leads to the geographical and collective spiritual heart of Islam is most likely to affect a person's spiritual heart and spiritual emotions.

To talk about personal spiritual emotions and what they change in a person, and connected with these the experiences a person had that led to the spiritual emotions, form something very personal. The accounts presented here tell us about the innermost self of a person and how traveling to the holy land changed her life. Different to other accounts of the hajj that mainly focus on the outside aspects of this important travel, as described by Tagliacozzo (2013), the data I present here, focuses on the inner aspects of a person's experiences.

\section{Feeling Khushu}

Leila came to Germany for her Ph.D in chemistry and has lived there for more than ten years. She is about 40 years old, married and has one daughter. She currently works in a Post-Doc position in a laboratory at a university in Berlin. Maryam has lived in Berlin for over 30 years. She is about 60 years old, a widow, has two children and works as a professional cleaner. Leila has been on hajj twice and thrice on umrah. She is currently planning her sixth visit to Mecca. Maryam went on hajj once and on umrah twice. Her last time in Mecca was together with Leila at the beginning of the year 2016. Both see their residence in Germany as a chance and possibility to go on hajj or umrah as often as possible. Undertaking the pilgrimage from Indonesia is not as easy as from Germany because long waiting lists, especially for the hajj, and higher prices make it more difficult to embark on this journey.
Leila and Maryam tried to describe their spiritual emotions during their hajj and umrah travel and the experiences that triggered them. The talks were very emotional and tears of remembrance, yearning, and gratefulness filled the silence between the sentences when words could not describe the emotions they probably felt at the moment. One predominant emotion that both women felt was peacefulness. A peacefulness that made them did not want to leave the places of pilgrimage anymore. Leila tried to explain how she felt when sitting near the Kaaba in the mosque in Mecca. This place is referred to as the Haram or Al-Haram Mosque, because its sanctity cannot be violated:

"When in the Haram it felt so pleasant, peaceful and secure. I felt like I do not want to leave ever again. All thoughts about my worldly life that usually preoccupy me were just gone. I felt so connected to God. So calm."

Leila further told me that her ritual prayer felt different as well. She felt as if God was talking to her through the recitation of the imam, the person leading the communal prayer. Although she did not understand the exact meaning of the words because she does not know Arabic and the litany used in the Islamic ritual prayer is always Arabic. Before visiting the holy land, Leila often went just through the movements of her prayer without her heart being present. While on hajj and umrah she learned to feel this special feeling called khushu in her prayer. When she described this feeling, she was unable to do so. Instead she compared it with the feeling when she stands alone in prayer at night when everybody else is asleep and she can pour out her heart to God. Maryam also referred to this special emotion of khushu, which was much stronger during prayer in Mecca and Medina compared to praying at home. Khushu is usually translated with focus of mind and heart during prayer. However, it 
can also be translated with feeling humility or humbleness in prayer. In addition, it also includes feeling connected to God, concentrating on God and eliminating any other thought except about God from one's mind. It includes quietude out of love and fear for God, gentlenes, and yearning.

Khushu in prayer is an essential emotion in Islam. It is also mentioned in the Qur'an: "It is the believers who are successful: those who are humble in their prayer" (23:1-2). In the Qur'an it is seen to be an important element of a successful prayer and manuals have been written on how to develop khushu in prayer. It is this element of prayer that connects a believer to God. In this sense, khushu can be counted as a religious emotion that is expected of the believer by the religious emotional regime of Islam. However, how to feel khushu is very personal and therefore, it is a spiritual emotion that can only truly be felt by the individual. It is a state of the heart of a believer. For example, it can be described as feeling khushu what Leila explained about her feeling that God was talking to her during the prayer in Mecca. To feel khushu and to learn how to feel it during prayer is something both informants learned during their travels to the holy land.

Although emotions are something rather intangible to the outsider and only really concrete to the individual that feels them, they, nevertheless, impact on a person's life. In this sense to feel khushu is a form of knowledge that is sought after while going on hajj and umrah. At the same time, Maryam explained that to be able to feel $k h u s h u$ will bring more divine reward for the person feeling it during prayer. Therefore, learning how to feel emotions during worship, to learn how to feel connected to God, to learn how to feel love, yearning, humbleness and humility for and in front of God can be counted to belong to the traditional reasons why Muslims go on hajj and umrah. These traditional reasons include the search for religious knowledge and to gain divine reward (Tagliacozzo 2013; van Bruinessen 1990). At the same time, to learn these spiritual emotions like $k h u s h u$ help a person to spiritually improve herself and her relationship with God. This spiritual self-improvement cannot be separated from influencing the person's worldly life and, as will be described below, can help to make a person a more active and productive member of society.

From the limited accounts presented here, it can be concluded that learning to feel khushu during pilgrimage seems to be a turning point in a pilgrim's life. The narratives illustrate that the whole hajj or umrah experience is life-changing. There is a time before a person went to Mecca and a time after it. To use Leila's words "You are not the same person when you go back home". In this sense, one can describe the process of the Muslim pilgrimage as a stage of liminality (Turner 1969), in which pilgrims find themselves in the transitory stage between two established social and also emotional and spiritual stages. Being in Mecca is a special transitory stage that impacts heavily on the individual's spiritual emotions, development, and selfimprovement. The last point is illustrated by Leila's case describe below.

\section{Spiritual Self-Improvement}

Traveling to the holy land of Islam is chosen for several reasons, one of them has been discussed above. Another reason for traveling to Mecca and Medina, is to facilitate a person's spiritual selfimprovement. Different studies show that both religious and secular pilgrims often share the trait of searching for meaningful and spiritual experiences, which can be described with different words, including transformation, enlightenment, lifechanging and consciousness-changing events (Digance 2006). As I have shown above, this is also the case for Muslims 
going on the Muslim pilgrimage. However, I propose that searching for meaningful and spiritual experiences is only the first step. As I will show with Leila's story, pilgrims also search for a way to spiritually improve their everyday lives back home. Spiritual self-improvement is seen as an impetus to improve the overall spirituality of an individual's everyday life.

Similar to Rudnyckyj's (2010) 'spiritual reform' in the macro context of an Indonesian company and post-new order economy in general, I see spiritual selfimprovement as a way for a person to become a more active and productive member of society. Here, society also includes the smallest unit, which is the nuclear family. Rudnyckyj argues that "efforts to develop faith represent not the end of development" (2010: 4) but "economic rationality and calculative reason" are introduced "into domains from which they were previously limited or excluded" (ibid.). These previously excluded domains include religion and spirituality.

This economic rationality and calculative reason can also be observed in Muslim women's choices to visit the holy land again and again as done for example by Leila. Economic rationality can be observed in the way she approached the realization of her wish to visit the holy land. When the urge to visit Mecca and Medina arose, Leila was still a Ph.D student who lived off a small stipend and was not able to afford the amount of money necessary to fulfill her wish. This fact did not deter her and she started to write letters to different embassies to sponsor her travel to the Hejaz. However, none of them replied and she had to wait until she was financially capable of affording to pay for herself and her husband.

Furthermore, although very much tight together with her spiritual emotions, the urge to go on hajj or umrah again and again also reflects a sense of economic rationality and calculative reason. Because, according to Leila, it is only in Mecca, close to the Kaaba, that she can improve herself spiritually the most. It is only there, where she feels closest to God and where she can come closer to her goal to become a better Muslimah. Furthermore, it is only through the different personal spiritual experiences she encounters on hajj or umrah that help her to improve her life back in Germany. One example illustrates this connection between spiritual experience in Mecca and Leila's life in Germany. While in Mecca, she attempted to pray in the holy mosque as often as possible. However, sometimes, she said, her laziness still overcame her and she stayed back in the hotel room to perform the ritual prayer. Once she finished her prayer, she saw the live broadcast from the holy mosque on television and suddenly felt a tremendous loss because she was not there in the mosque but prayed by herself in the hotel room.

The loss she felt missing the congregational prayer was eventually transformed by Leila into a motivation to take greater care of her ritual prayers. After she returned home and resumed work at the laboratory, she began to take great care of always praying in time and if possible as early as possible within the given time frame for the respective prayer. This in turn, as she described, had a positive effect on her work in the lab because she was now able to work more effectively. She was able to finish the prepared samples quicker and was even capable to achieve more than what was required of her. This experience at her work place was sufficient proof for Leila to plan to travel to Mecca again. She felt that the spiritual experiences and lessons she had made in the holy land had an immediate effect on her life back home. Her performance as a Muslimah as well as her performance as a worker in the laboratory improved. 
In addition, Leila's spiritual experiences also have to be understood with regards to her expectations for her afterlife because she believes that her spiritual self-improvement will benefit her in her life after death. To become a better Muslimah does not only influence her worldly life but first and foremost is expected to have a positive effect on her afterlife, so she hopes. The belief in paradise and hell forms a strong force in pushing Muslims to change their lives to the better and to become pleasing to God. To do a good deed and to abstain from bad deeds is believed to affect one's afterlife. While it is especially desirable to do good deeds solely for the sake of God, certain economic rationality and calculative reason (Rudnyckyj 2010) cannot be denied entirely because one expects a reward in the afterlife for the actions done in this world. Therefore, Leila's pilgrimage to the holy land has to be also understood in terms of her aim to improve her afterlife and to avoid punishment for bad actions and sins committed in this life.

I argue that Leila's realization about the impact of her spiritual experiences in the holy land on her life in this world can be understood on two different levels. Firstly, economic rationality and calculative reason, as described by Rudnyckyj (2010), certainly play a role in Leila's choice to go again and again to the Hejaz in order to improve her spirituality and in consequence her worldly life as a working woman but also the prospects for her afterlife. Secondly, emotional satisfaction and the spiritual high Leila felt during her stay in Mecca cannot be overlooked. That is why for future studies on pilgrimage and spiritual travel, I propose to focus on pilgrim's spiritual emotions to better understand why people undertake pilgrimages and many travel to the same pilgrimage destination again and again.

Another important concept, barakah, roughly translated as divine blessing, was mentioned by both informants. It also seem to play a significant role in why Muslims choose to go again and again to the holy land. Muslims believe that the pilgrimage itself and the places visited have an inherent divine blessing in them. The appointed time for the hajj in the Islamic month of Dhul Hijjah is supposed to carry additional blessings. Pilgrims hope that these special divine blessings are transferred to them and into their lives. The length of this paper does not allow to discuss this concept in detail here.

\section{Conclusion}

In this article, I tried to show how traveling to the Muslim holy land in Mecca on hajj and umrah can be a life-changing experience for the pilgrim undertaking the journey. Furthermore, I showed that there exist multi-layered reasons to undertake the Muslim pilgrimage. People's reasons for going on hajj and umrah need to be understood by looking at what kind of spiritual emotions are triggered through the experiences they make in the holy land, and how these spiritual emotions eventually impact the person's spiritual and worldly life. Spiritual self-improvement can lead to change in a person's worldly life and is able to contribute to making the person a more active and proactive member of society.

Furthermore, I tried to show that spiritual self-improvement in itself contains economic rationality and calculative reason because one of the main reasons a person wants to improve herself is to gain benefit in the afterlife. Here, I explicitly illustrated my point with the spiritual emotion of khushu that both of my informants learned while on hajj and umrah.

In addition, I argued that spiritual emotions can be viewed as being part of the knowledge a person aims to acquire during her journey to Mecca. At the same time, to learn how to feel spiritual emotions can lead to additional divine reward, another reason, 
why Muslims choose to undertake the hajj or umrah. Spiritual emotions that derive from different experiences while on hajj or umrah play an important part in understanding why Muslims choose to visit the holy land again and again. Similar to what Collins-Kreiner (2018) described about Westerners visiting the Dalai Lama, the two women described in this article, undertook their journeys with specific educational and spiritual motivations, in order to return home feeling spiritually stronger and more fulfilled.

I have further shown that mobility in connection with going on hajj or umrah is both internal as well as external. The women have undergone and are still undergoing internal mobility because of the impact their pilgrimages and the spiritual experiences they made have had on them. Something has been changing within them. They have made a move towards a different life or have changed part of their lives. The external mobility is the journey itself. However, this point needs further investigation in a later article.

Further research will be investigating what spiritual emotions Muslims feel during their pilgrimage and how these spiritual emotions impact on their lives. It is necessary to understand on a broader scale Muslim's spiritual motivation in deciding to visit the holy land and why many of them want to and plan to go again or dream of going again. In order to obtain a more comprehensive view, around twenty people will be interviewed about their pilgrimage experiences. In addition, it would be interesting to compare what kind of spiritual emotions are felt by people of other religions and beliefs who undertake their specific pilgrimages or spiritual journeys.

\section{References}

Ahmad, F. (2011). Religion and Spirituality in Coping with Advanced Breast Cancer:
Perspectives from Malaysian Muslim Women. Journal of Religion and Health, 50 (1) 36-45.

Barber, R. (1993). Pilgrimages. London: The Boydell Press.

Cohen, E. (1992). Pilgrimage Centers, Concentric and Excentric. Annals of Tourism Research, 19 (1) 33-50.

Collins-Kreiner, N. (2018). PilgrimageTourism: Common Themes in Different Religions. International Journal of Religious Tourism and Pilgrimage, 6 (1) 8-17.

Collins-Kreiner, N. \& Gatrell, J. D. (2006). Tourism, Heritage and Pilgrimage, The Case of Haifa's Baha'i Gardens. Journal of Heritage Tourism, 1 (1) 32- 50.

Digance, J. (2003). Pilgrimage at Contested Sites. Annals of Tourism Research, 30 (1) 143-159.

Digance, J. (2006). Religious and Secular Pilgrimage, in Timothy, D.J. \& Olsen, D.H. (Eds.) Tourism, Religion and Spiritual Journeys. London: Routledge, 36-48.

Eickelman, D. F., \& Piscatori, J. (1990). Social Theory in the Study of Muslim Societies. In D. F. Eickelman \& J. Piscatori (Eds.), Muslim Travellers: Pilgrimage, Migration and the Religious Imagination. Berkeley, Los Angeles: The University of California Press.

Fredrickson, B. L. (2002). How does Religion Benefit Health and Well-Being? Are Positive Emotions Active Ingredients?. Psychological Inquiry, 13 (3) 209-213.

Gallagher, S. K., \& Newton, C. (2009). Defining Spiritual Growth: Congregations, Community, and Connectedness. Sociology of Religion, 70 (3) 232-261.

Greenfield, E. A. (2009). Do Formal Religious Participation and Spiritual Perceptions Have Independent Linkages with Diverse Dimensions of Psychological WellBeing?. Journal of Health and Social Behavior, 50 (2) 196-212. 
Malamud, M. (1996). Gender and Spiritual Self-Fashioning: The Master-Disciple Relationship in Classical Sufism. Journal of the American Academy of Religion, 64 (1) 89-117.

Nolan, M.L. \& Nolan, S. (1989). Christian Pilgrimage in Modern Western Europe. Chapel Hill: The University of North Carolina Press.

Parveen, Babli. (2014). The Eclectic Spirit of Sufism in India: An Appraisal. Social Scientist, 42 (11/12) 39-46.

Poria, Y., Butler, R. \& Airey, D. (2003). The Core of Heritage Tourism, Distinguishing Heritage Tourists From Tourists in Heritage Places. Annals of Tourism Research, 30 (1) 238-254.

Poria, Y., Butler, R. \& Airey, D. (2004). How Tourists Decide Which Heritage Site to Visit. Tourism Review, 59(2) 12-16.

Powers, Paul R. (2004). Interior, Intentions, and the "Spirituality" of Islamic Ritual Practice. Journal of the American Academy of Religion, 72 (2) 425-459.

Riis, O.; Woodhead, L. (2010). A Sociology of Religious Emotions. Oxford: Oxford University Press.

Rudnyckyj, D. (2010). Spiritual Economies: Islam, Globalization, and the Afterlife of Development. Ithaca: Cornell University Press.

Sharp, S. (2010). How does Prayer Help Manage Emotions?. Social Psychology Quarterly, 73 (4) 417-437.

Smith, V. L. (1989). Hosts and Guests-The Anthropology of Tourism. Pennsylvania: University of Pennsylvania Press.

Smith, V. L. (1992). Introduction. The Quest in Guest. Annals of Tourism Research, 19 (1) 1-17.

Tagliacozzo, E. (2013). The Longest Journey: Southeast Asians and the Pilgrimage to Mecca. Oxford, New York: Oxford University Press.

Turner, V. (1969 (2008)). Ritual, AntiStructure, and Religion. New
Brunswick, London. Aldine Transaction.

van Bruinessen, M. (1990). Mencari Ilmu dan Pahala di Tanah Suci: Orang Nusantara Naik Hajji. Ulumul Qur'an, 2 (5) 4249.

Vukonić, B. (1996). Tourism and Religion. London: Elsevier Science Ltd.

Vukonić, B. (2002). Religion, Tourism and Economics, a Convenient Symbiosis. Tourism Recreation Research, 27 (2) 59-64.

Wolf, R. K. (2000). Embodiment and Ambivalence: Emotion in South Asian Muharram Drumming. Yearbook for Traditional Music, 32, 81-116.

\section{About The Author}

Claudia Seise obtained her Ph.D in Southeast Asian Studies from Humboldt University Berlin. Her dissertation is entitled Religioscapes in Muslim Indonesia: Personalities, Institutions, and Practices. She currently works as an assistant professor at the International Islamic University Malaysia. She is a co-founder of the UluIlir-Institute in Palembang, Indonesia. 